\title{
PEMBUATAN BIOETANOL DARI NIRA AREN (Arenga pinnata Merr) MENGGUNAKAN Saccharomyces cerevisiae
}

\author{
BIOETHANOL PRODUCTION FROM PALM JUICE (Arenga pinnata Merr) USING \\ Saccharomyces cerevisiae
}

\author{
Meilani M Manurung*, Gusti Handayani, Netti Herlina \\ Departemen Teknik Kimia, Fakultas Teknik, Universitas Sumatera Utara, \\ Jl. Almamater Kampus USU, Medan 20155, Indonesia \\ *Email : meilani12manurung@gmail.com
}

\begin{abstract}
Abstrak
Bioetanol merupakan senyawa alkohol yang diperoleh dari proses fermentasi biomassa dengan bantuan mikroorganisme Penelitian ini bertujuan untuk mengetahui pengaruh kecepatan agitasi dan volume starter terhadap kadar dan yield bioetanol yang dihasilkan dari nira aren (Arenga pinnata Merr). Katalis yang digunakan adalah Saccharomyces cerevisiae. Variabel-variabel yang diamati antara lain kecepatan agitasi dan volume starter pada proses fermentasi. Tahapan pertama adalah pembuatan starter yang kemudian dilanjutkan dengan proses fermentasi secara anaerobik. Hasil fermentasi kemudian didistilasi pada temperatur $88^{\circ} \mathrm{C}$. Hasil penelitian menunjukkan bahwa semakin tinggi volume starter dan kecepatan agitasi maka kadar dan yield bioetanol yang dihasilkan akan semakin tinggi hingga mencapai titik maksimum yang diperoleh pada agitasi $100 \mathrm{rpm}$ dan volume starter $35 \%$ sebesar $47,618 \%(\mathrm{v} / \mathrm{v})$ dan $48,1411 \%$. Jika melebihi titik tersebut maka perubahan kecepatan agitasi dan penambahan volume starter akan menurunkan kadar dan yield etanol yang dihasilkan.
\end{abstract}

Kata kunci : bioetanol, fermentasi, nira aren, saccharomyces cerevisiae.

\begin{abstract}
Bioethanol was an alcohol substance which can be obtained by biomass fermentation process. The purpose of this study was to determine the effect of agitation and volume of starter on yield and concentration of bioethanol produced from palm juice (Arenga pinnata Merr). Catalyst used was Saccharomyces cerevisiae. Observed variables were agitation and volume of starter in anaerobic fermentation. The experiment started with preparation of a starter followed by fermentation process. The product obtained from distillation process at temperature of $88{ }^{\circ} \mathrm{C}$. The results showed that the higher agitation speed and volume of starter, yield and concentration of bioethanol will be higher. The highest concentration and yield obtained on the condition at a agitation of $100 \mathrm{rpm}$ and $35 \%$ starter amounted to $47.618 \%(v / v)$ and $48.1411 \%$. If it exceed that point, the changes of agitation and the addition of starter did not increase the concentration and yield of ethanol produced.
\end{abstract}

Keywords : bioethanol, fermentation, palm juice, saccharomyces cerevisiae

\section{Pendahuluan}

Bioetanol atau etil alkohol $\left(\mathrm{C}_{2} \mathrm{H}_{5} \mathrm{OH}\right)$ sebagai bahan bakar yang ramah lingkungan dan juga terbarukan menjadi perhatian dunia dewasa ini. Hal ini dibuktikan dengan semakin meningkatnya produksi bioetanol dari tahun ke tahun yakni 17,3 juta liter pada tahun 2000, meningkat menjadi 46 juta liter di tahun 2007 dan diestimasi akan meningkat secara drastis pada tahun 2020 yakni sebanyak 125 juta liter [2].

Bahan baku utama pembuatan bioetanol dengan proses fermentasi pada dasarnya berasal dari glukosa, pati dan lignoselulosa $[1,26]$. Bioetanol dapat diproduksi dari berbagai jenis biomassa seperti jagung, gandum, selulosa, alga dan ampas tebu yang mana bahan baku ini berwujud padatan [3, 24]. Adapun bahan baku cair yang pernah digunakan sebagai bahan baku pembuatan bioetanol adalah nira kelapa, nira nipah (Nypa fructicans), dan nira aren (Arenga pinnata Merr) [6, 11, 25]. Kelebihan bahan baku cairan (nira) adalah karena nira merupakan larutan gula yang dapat langsung memulai proses fermentasi sehingga dapat mempersingkat tahapan produksi etanol [23]. Hal ini berbeda jika bahan baku berasal dari pati dan selulosa, dimana pati harus melalui proses hidrolisis untuk masuk ke tahapan fermentasi gula sedangkan selulosa harus dikonversi terlebih dahulu untuk mendapatkan gula dengan bantuan mineral asam [14].

Pembuatan bioetanol berbahan baku gula dan pati melalui proses fermentasi dengan bantuan mikroba Saccharomyces cerevisiae adalah metode yang paling umum dan sering digunakan di industri [2]. Saccharomyces cerevisiae digunakan untuk memecah glukosa dalam proses fermentasi 
untuk menghasilkan kadar etanol yang tinggi [4, 13].

\section{Teori}

Bioetanol merupakan etanol yang diperoleh dari bahan berbasis biomasa atau sumber yang terbarukan seperti dari berbagai tanaman yang mengandung karbohidrat, gula serta tanaman berselulosa. Bioetanol berwujud cairan yang merupakan hasil dari proses fermentasi gula dimana terjadi perombakan senyawa organik dengan melibatkan mikroorganisme [5, 21].

Etanol atau etil alkohol $\left(\mathrm{C}_{2} \mathrm{H}_{5} \mathrm{OH}\right)$ memiliki karakteristik mudah terbakar, mudah menguap, larut dalam air membentuk larutan azeotrop, tidak karsinogenik dan tidak memberikan dampak pencemaran pada lingkungan yang signifikan [9].

Nira yang manis diperoleh dari aren dengan cara penyadapan. Nira disadap dari tongkol bunga jantan dapat menghasilkan 8-12 liter per hari dengan 2 kali penyadapan. Nira segar mengandung gula $11-14 \%$, abu $0,04 \%$, protein $0,2 \%$ dan kadar lemak 0,02\% [20]. Kandungan gula yang cukup tinggi pada nira aren menyebabkan nira mudah rusak selama penyimpanan. Hal ini disebabkan karena adanya peristiwa fermentasi yang dapat menurunkan kualitas nira [16].

Secara sederhana proses fermentasi adalah proses konversi $1 \mathrm{~mol}$ glukosa menjadi $2 \mathrm{~mol}$ etanol dan 2 mol karbondioksida dengan bantuan enzim. Reaksi kimianya adalah sebagai berikut [8] :

$$
\mathrm{C}_{6} \mathrm{H}_{12} \mathrm{O}_{6} \longrightarrow 2 \mathrm{C}_{2} \mathrm{H}_{5} \mathrm{OH}+2 \mathrm{CO}_{2}
$$

Mikroorganisme yang paling banyak digunakan untuk memproduksi bioetanol adalah ragi, khususnya Saccharomyces cerevisiae. Saccharomyces cerevisiae sering dipilih untuk produksi etanol karena sangat baik dalam melakukan fermentasi dan kemampuannya untuk tumbuh dengan cepat dibawah kondisi anaerobik dan toleransi yang tinggi terhadap etanol [22].

\section{Metodologi Penelitian}

Bahan-bahan yang digunakan dalam penelitian ini adalah nira aren (Arenga pinnata Merr), NPK, dan S.cerevisiae. Peralatan yang digunakan dalam penelitian ini adalah erlenmeyer, beaker glass, hemositometer, refraktometer, autoclave, labu leher tiga, hot plate, dan agitator.

\section{Prosedur Pembuatan Starter}

Sebagai langkah pertama, disterilkan semua peralatan yang akan digunakan dengan autoclave selama 15 menit pada suhu $121{ }^{\circ} \mathrm{C}$. Dipanaskan nira segar pada suhu $80{ }^{\circ} \mathrm{C}$. Nira didinginkan hingga suhu ruangan kemudian dimasukkan satu oase s.cerevisiae dan diaduk hingga merata. Starter didiamkan pada konisi ruangan selama 48 jam. Selanjutnya dilakukan perhitungan jumlah s.cerevisiae dengan hemositometer.

\section{Prosedur Fermentasi}

Semua peralatan yang akan digunakan disterilkan dengan autoclave selama 15 menit pada suhu $121{ }^{\circ} \mathrm{C}$. Dipanaskan nira aren segar pada suhu $80{ }^{\circ} \mathrm{C}$. Kadar gula nira di analisis dengan refraktometer. Dicampurkan nira aren dengan larutan starter sebanyak $15 \%$ (v/v) dari total volume campuran $850 \mathrm{ml}$. Ditambahkan NPK 0,4\% (m/m) ke dalam larutan. Campuran diaduk di rotary shaker dengan kecepatan agitasi 75 rpm selama 24 jam pada suhu ruangan. Dimasukkan hasil fermentasi ke dalam peralatan distilasi, kondisi operasi diatur pada suhu $88{ }^{\circ} \mathrm{C}$. Distilat di tampung dengan erlenmeyer dan diukur volumenya.

\section{Analisis Produk}

Analisis terhadap bioetanol yang dihasilkan meliputi analisis karakteristik dengan Fourier Transform Infra Red (FTIR), perhitungan densitas, kadar bioetanol, specific gravity (sg), API Gravity dan nilai kalor.

\section{Hasil dan Pembahasan}

\section{Karakterisasi FTIR (Fourier Transform Infra Red) Etanol}

Karakterisasi FTIR (Fourier Transform Infra Red) etanol dari nira aren dilakukan untuk mengidentifikasi gugus fungsi dari senyawa etanol. Karakteristik FTIR etanol dapat dilihat pada gambar 1 .

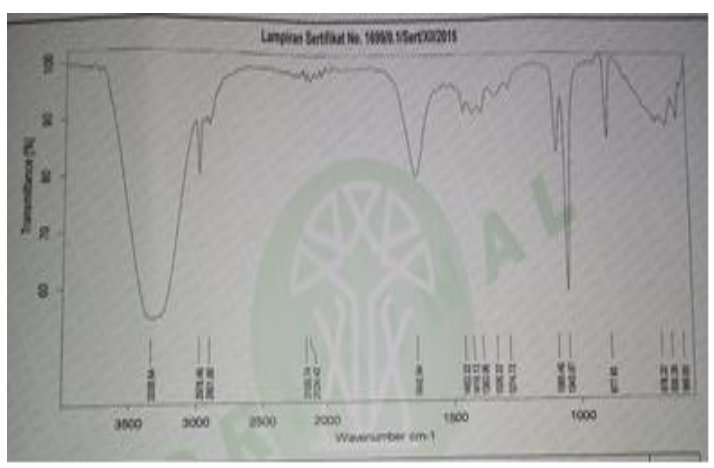

\section{Gambar 1. Spektrum FTIR (Fourier Transform Infra Red) Etanol Dari Nira Aren}

Data spektrum etanol dengan mencermati puncak serapan gelombang yang diperlihatkan dapat dianalisis bahwa pada bilangan gelombang $3338,64 \mathrm{~cm}^{-1}$ terdapat serapan yang kuat dan melebar, hal ini menunjukkan adanya interaksi antara molekul elektronegatif $\mathrm{O}$ dengan positif $\mathrm{H}$ yang membentuk ikatan hidrogen. Hal ini berarti terdapat gugus - $\mathrm{OH}$ dalam sampel. Bilangan gelombang pada $2978,46 \mathrm{~cm}-1$ menunjukkan 
adanya ikatan alkana (C-H) yang kuat. Serta pada bilangan gelombang $1043,87 \mathrm{~cm}^{-1}$ terdapat ikatan $\mathrm{C}-\mathrm{OH}$. Maka dari hasil analisis FTIR ini dapat disimpulkan bahwa sampel mengandung etanol.

\section{Pengaruh Volume Starter dan Agitasi terhadap Kadar Bioetanol}

Salah satu indikator keberhasilan dari proses fermentasi adalah kadar bioetanol yang dihasilkan. Produk hasil fermentasi selanjutnya didistilasi. Distilat kemudian dianalisis kadar bioetanolnya dengan melakukan perhitungan densitas yang selanjutnya diinterpolasi dalam hubungan konversi densitas dan kadar etanol [19].

Dari hubugan densitasi dan kadar etanol, dibuat kurva kadar bioetanol (\% v/v) vs volume starter (\% v/v). Kurva dapat dilihat pada gambar 2.

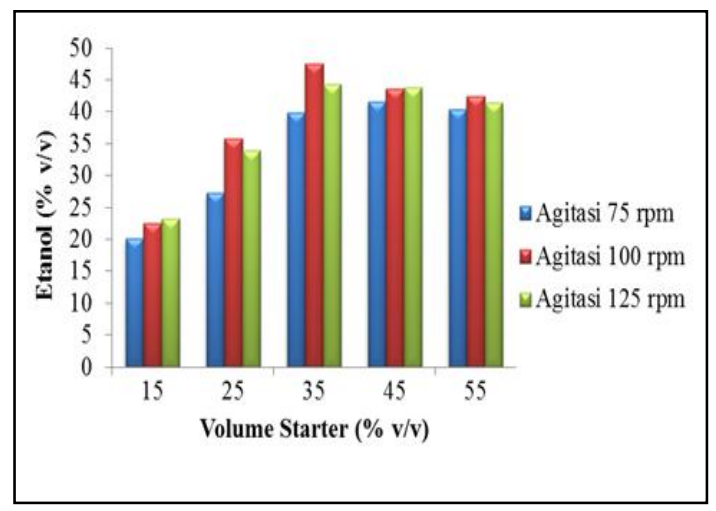

Gambar 2. Pengaruh Volume Starter dan Agitasi Terhadap Kadar Bioetanol

Kismurtono meneliti bahwa volume starter yang semakin tinggi akan menghasilkan kadar bioetanol yang semakin tinggi juga untuk waktu fermentasi 24 jam dengan menggunakan bahan baku nira aren dan S.cerevisiae sebagai katalisnya [11]. Hal ini didukung juga oleh hasil penelitian Eka dan Halim, yang menyatakan bahwa semakin banyak persen starter yang dicampurkan ke dalam substrat maka jumlah S.cerevisiae juga akan semakin banyak sehingga glukosa yang dikonversi menjadi etanol juga akan semakin meningkat [7]. Namun dari hasil penelitian ini diperoleh data bahwa penambahan volume starter melebihi titik tertentu tidak meningkatkan kadar bioetanol yang dihasilkan. Hal ini disebabkan oleh populasi sel yang tinggi. Kondisi pertumbuhan dan metabolisme pada populasi sel yang tinggi tidak diharapkan karena akan terjadi gangguan terhadap akses nutrisi yang diakibatkan keterbatasan ruang gerak sel [15]. Tingginya populasi sel juga akan meningkatkan jumlah karbondioksida sebagai produk sampingan dan etanol sebagai produk utama. Dalam proses fermentasi batch baik produk utama dan produk samping akan terakumulasi sehingga menjadi inhibisi bagi pertumbuhan mikroba [17].
Jumlah sel dalam media fermentasi sangat mempengaruhi kadar bioetanol yang dihasilkan, selain itu variasi agitasi yang dilakukan juga menunjukkan pengaruh yang cukup signifikan. Oktaviani dkk melakukan penelitian mengenai pengaruh laju pengadukan terhadap biokonversi bioetanol, dimana dari hasil penelitiannya menyatakan bahwa tujuan dari pengadukan adalah untuk mencegah sel mikroorganisme membentuk gumpalan yang selanjutnya akan mengganggu perkembangbiakan sel akibat tidak mendapatkan makanan yang cukup dari substrat. Selain itu hasil penelitiannya menunjukkan bahwa kecepatan pengadukan berbanding lurus dengan kadar bioetanol hingga mencapai titik maksimum, dimana setelah melewati titik tersebut penambahan kecepatan pengadukan akan menurunkan kadar bioetanol yang dihasilkan. Jeckson dkk meneliti bahwa hal itu disebabkan oleh pengadukan yang terlalu cepat dapat mengganggu metabolisme yeast $[10,18]$.

\section{Pengaruh Volume Starter dan Agitasi terhadap Yield Bioetanol}

Efisiensi penggunaan substrat untuk menghasilkan etanol dinyatakan dalam yield bioetanol. Semakin tinggi nilai yield, maka semakin efisien proses fermentasi tersebut [10].

Pengaruh volume starter dan agitasi terhadap yield bioetanol dapat dilihat pada gambar 3 .

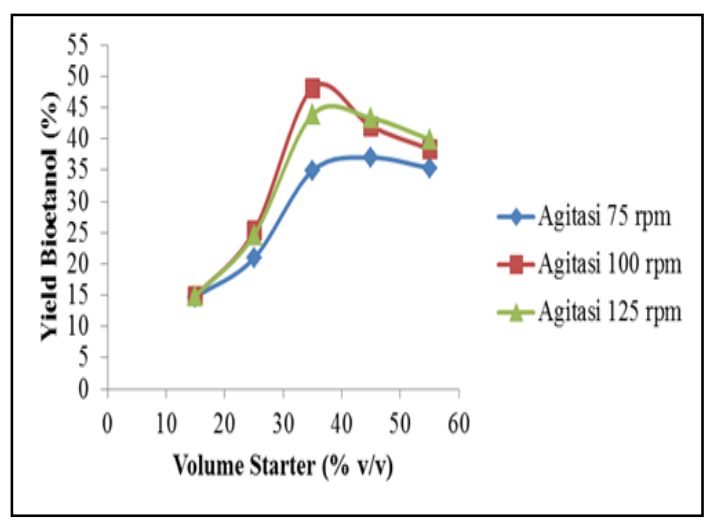

Gambar 3. Pengaruh Volume Starter dan Agitasi Terhadap Yield Bioetanol

Kismurtono meneliti bahwa volume starter yang semakin tinggi akan mereduksi gula semakin cepat menjadi bioetanol sehingga yield bioetanol yang dihasilkan akan semakin tinggi hal ini akan menghasilkan kadar bioetanol yang semakin tinggi juga [11]. Namun dari hasil penelitian ini diperoleh data bahwa penambahan volume starter melebihi titik tertentu tidak meningkatkan yield yang dihasilkan sejalan dengan hasil yang diperoleh untuk kadar bioetanol.

Jumlah sel dalam media fermentasi sangat mempengaruhi konversi gula menjadi bioetanol 
dalam penelitian ini, selain itu variasi agitasi yang dilakukan juga menunjukkan pengaruh yang cukup signifikan. Oktaviani dkk menyatakan bahwa kecepatan pengadukan berbanding lurus dengan kadar dan yield bioetanol hingga mencapai titik maksimum, dimana setelah melewati titik tersebut penambahan kecepatan pengadukan akan menurunkan kadar dan yield bioetanol yang dihasilkan [18]. Jeckson dkk meneliti bahwa hal itu disebabkan oleh pengadukan yang terlalu cepat dapat mengganggu metabolisme yeast [10]. Hal yang sama diteliti juga oleh Kurniawan dkk bahwa waktu kontak mikroorganisme dengan substrat lebih cepat sehingga glukosa yang terdapat pada substrat tidak termanfaatkan dengan baik [12].

\section{Kesimpulan}

Kesimpulan yang diperoleh bahwa volume starter dan agitasi berpengaruh dalam proses fermentasi. Semakin tinggi volume starter dan kecepatan agitasi maka kadar dan yield bioetanol yang dihasilkan akan semakin tinggi hingga mencapai titik maksimum pada perlakuan agitasi $100 \mathrm{rpm}$ dan volume starter $35 \%$ yaitu masingmasing sebesar 47,618 (\% v/v) dan 48,1411\%. Jika melebihi titik tersebut penambahan volume starter dan kecepatan agitasi akan menurunkan kadar dan yield bioetanol yang dihasilkan.

\section{Daftar Pustaka}

[1] Alvira, P., Pejo, E. Tomas., Ballesteros, M., Negro, M.J., Pretreatment Technologies For An Efficient Bioethanol Production Process Based On Enzymatic Hydrolysis: A Review. Bioresource Technology 101 (2009) : 48514861

[2] Aparicio, Susana López., Hak, Claudia., Sundvor, Ingrid., and Sundseth, Kyrre.. Understanding effects of bioethanol fuel use on urban air quality: An integrative approach. Energy Procedia 58 (2014) : $215-220$

[3] Cardona, C.A., J.A. Quintero, and I.C. Paz. Production of bioethanol from sugarcane bagasse: Status and perspectives. Bioresource Technology 101 (2010) : 47544766

[4] Cheng, Ngoh Gek., Hasan, Masitah., Kumoro, Andri Chahyo., Ling, Chew Fui., Tham, Margaret. Production of Ethanol by Fed-Batch Fermentation. Pertanika J.SCi \& Technol 17 (2) (2009) : 399-408. ISSN: 0128-7680

[5] Hasan, M.H., Mahlia, T.M.I., and Nur, Hadi. A Review on Energy Scenario and Suistanable Energy in Indonesia. Renewable and Suistanable Energy Reviews 16 : 23162328. (2012)
[6] Effendi, Dedi Soleh. Prospek Pengembangan Tanaman Aren (Arenga pinnata Merr) Mendukung Kebutuhan Bioetanol di Indonesia. Perspektif Vol.9, No.1 (2010). Hal. 36-46. ISSN : 1412-8004.

[7] Eka, Agustinus dan Halim, Amran. "Pembuatan Bioetanol dari Nira Siwalan Secara Fermentasi Fese Cair Menggunakan Ferminpan". Jurusan Teknik Kimia. Fakultas Teknik. Universitas Diponegoro.

[8] Haggstrom, Caroline., Rova, Ulrika., Brandberg., Hodge, David B. Integration of Ethanol Fermentation With Second Generation Biofuels Technologies (2014)

[9] Jannah, Asyeni Miftahul. Proses Fermentasi Hidrolisat Jerami Padi untuk Menghasilkan Bioetanol. Jurnal Teknik Kimia No. 1, Vol. 17. (2010)

[10] Jeckson, Edie., Ahmad, Adrianto., dan Muria, Sri Rezeki. Pengaruh Laju Pengadukan dalam Pembuatan Bioetanol dari Limbah Serabut Buah Sawit Menggunakan Saccharomycess cerevisiae. JOM Fteknik Volume 1 No.2 (2014)

[11] Kismurtono, Muhammad. Fed-batch Alcoholic Fermentation of Palm Juice (Arenga pinnata Merr) : Influence of the Feeding Rate on Yeast, Yield and Productivity. ISSN : 2049-344 (2012)

[12] Kurniawan, R., Juhanda, S., Syamsudin, R., dan Lukman., MA. Pengaruh Jenis dan Kecepatan Pengadukan pada Fermentasi Etanol Secara Sinambung dalam Bioreaktor Tangki Berpengaduk Sel Tertambat. Jurnal STU 10 November 2011, ISSN : 1693-1750 Itenas.

[13] Lee, Wen Shiang., Chen, I Chu., Chang, Cheng-Hsiung., Yang, Shang Shyng. Bioethanol Production From Sweet Potato by Co-Immobilization of Saccharolytic Molds and Saccharomyces cerevisiae. Renewable Energy 39 (2012) : 216-222.

[14] Lin, Yan., and Tanaka,. Shuzo. Ethanol Fermentation from Biomass Resources: Current State and Prospects. Appl Microbiol Biotechnol 69 (2006) : 627-64

[15] Mukhtar, K., Asgher, M., Hussain, K., dan Ziaul-Husnain, S. Comparative study on two comercial strains of s.cerevisiae for optimum ethanol productionon industrial scale. Journal of Biomedicine and biotechnology. (2010)

[16] Mulyawanti, Ira., Nurdi Setyawan, Andi Nur Alam Syah, Risfaheri. Evaluasi Mutu Kimia, Fisika Dan Mikrobiologi Nira Aren (Arenga Pinnata) Selama Penyimpanan. Jurnal Agritech, Vol. 31, No. 4 (2011)

[17] Nguyen, Viet D., Aurensenia, Joseph., Kosuge, Hitoshi., Tan, Raymon R., dan 
Brondial, Yolanda. Vacuum fermentation Integrated with separation process for ethanol production. Biochemical Engineering Journal 55 (2011) : 206-214

[18] Oktaviani, Intan., Ahmad, Adrianto., dan Chairul. Pengaruh Laju Pengadukan Terhadap Biokonversi Reject Nanas Menjadi Bioetanol. JOM Fteknik Volume 2 No.1 (2015)

[19] Perry, Robert H dan Green, Don. Perry's Chemical Engineering Hanbook. Edisi Keenam. (1958)

[20] Pontoh, Julius., Gunawan, Indriani., Fatimah, Feti. Analisis Kandungan Protein Dalam Nira Aren. Chem Prog, Vol. 4, No.2 (2011)

[21] Romdhoni, Machrus Afif. Pembuatan Bioetanol Darisen Teh Hijau sebagai Bahan Bakar Alternatif. JTM Vol. 03. No. 02 (2014) : 11-19

[22] Shahirah, Mohd Nasir Nor., Gimbun, Jolius., Pang, Sook Fun., Zakria, Rossyuhaida Mohd., Cheng, Chin Kui., Chua, Gek Kee., dan Asras, Mohd Fazli Farida. Influence of Nutrient addition on the bioethanol yield from oil palm trunk sap fermented by s.cerevisiae. Journal of Industrial and Engineering Chemistry. 2014

[23] Tangkuman, Herling D., Rorong, Johnly A., Pandara, Dolfie., Tamuntuan, Gerald. Produksi Bioetanol dari Nira Aren Menggunakan Energi Geothermal. Chem Prog, Vol. 3, No. 1 (2010)

[24] Wei, Ping, Li-Hua Cheng, Lin Zhang, XinHua $\mathrm{Xu}$, Huan-lin Chen, and Gao, Cong-jie. A review of membrane technology for bioethanol production. Renewable and Sustainable Energy Reviews 30 (2014) : 388-400

[25] Wijaya, I Made Anom Sutrisna., Arthawan, I Gusti Ketut., Sari, Anis Novita. Potensi Nira Kelapa Sebagai Bahan Baku Bioetanol. Jurnal Bumi Lestari, Vol. 12, No.1 (2012). Hal. 85-92

[26] Zheng, Dao-Qiong., Wu, Xue-Chang., Tao, Xiang-Lin., Wang, Pin-Mei., Ping Li, XiaoQin Chi, Yu-Dong Li, Qing-Feng Yan, And Zhao, Yu-Hua. Screening and Construction Of Saccharomyces Cerevisiae Strains with Improved Multi-Tolerance and Bioethanol Fermentation Performance. Bioresource Technology 102 (2011) : 3020-3027 